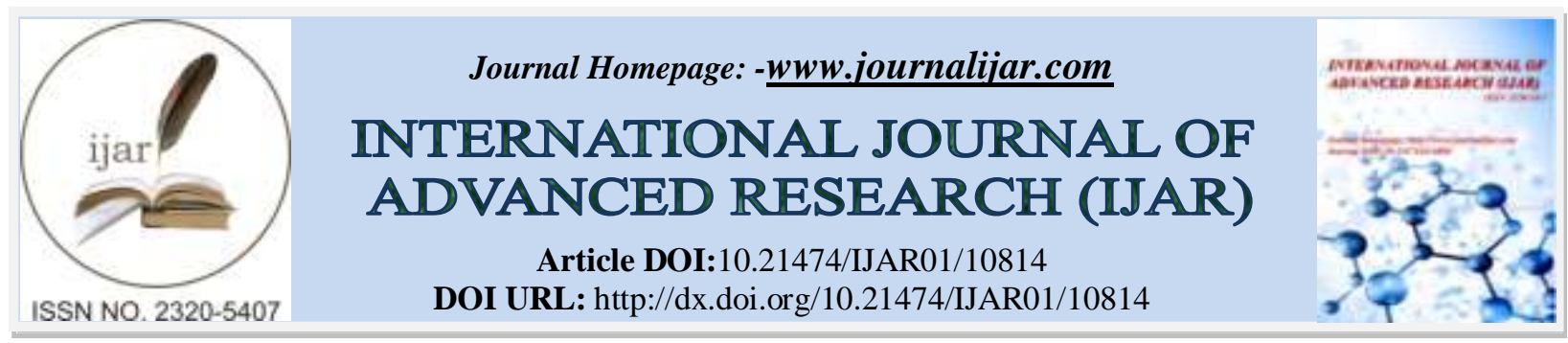

RESEARCH ARTICLE

\title{
EXPLORING THE INTER-LINKAGE: ENVIRONMENTAL STRESS, MIGRATION AND ENVIRONMENTAL DEGRADATION
}

\author{
Dr. Pinky Baruah \\ Department of Zoology, Guwahati College. Ghy-781021.
}

\section{Manuscript Info \\ Manuscript History \\ Received: 12 February 2020 \\ Final Accepted: 14 March 2020 \\ Published: April 2020}

Key words:-

Environmental Stress, Migration,

Environmental Degradation

\begin{abstract}
Environmentalproblems are multidisciplinary in nature. Environmental conditions, both favourable and extreme, have been the cause of displacement of people around the world. Recent studies have predicted that in the near future more people are likely to migrate due to environment related factors. Environmental stress drives migration forcing people to go in search of shelter and livelihood. But this in turn has put on an additional burden on the resources by encroaching on the new environment thereby increasing the fragility and degradation of the local environment leading to urban environment problems. This paper is an attempt to study the condition of environmental migrants and establish their linkage with environmental stress and environmental degradation. The paper particularly focuses on Guwahati, the gateway to Northeast India and how the migrants are facing the burden of environmental stress as they are exposed to new vulnerabilities.
\end{abstract}

Copy Right, IJAR, 2020,. All rights reserved.

\section{Introduction:-}

Climate Change is the present concerning issue of the world. In both national and international forums there have been discussions regarding climate change and environmental deterioration as a cause of insecurity. Human activities are the leading forces behind the decline of the environment resulting in climate change. An Intergovernmental Panel on Climate Change (IPCC) report depicts that global temperatures are so far the warmest to have been experienced since 1885 (Ahmed et al., 2018). These temperatures are expected to increase further to a margin of about $6.4^{\circ} \mathrm{C}$ by the year 2100 due to global warming. Global warming has increased due to accumulation of greenhouse gases $(\mathrm{GHG})$ in the atmosphere. This increase in global mean temperature ultimately leads to increase in water levels in the oceans and lakes mainly due to melting of glaciers. The resultant implications are displacement of people to other regions for livelihood and safety. The natural resources are destroyed when natural catastrophes occur causing scarcity which leads to competition for available resources. Developing countries are the most predisposed to these calamities, requiring that more funds be committed to facilitating environmental friendly activities and responding to risks of climate change (Ahmed et al., 2018).

Migration is an old phenomenon of human movement across the world. Migration, environmental change, urbanization and development are complex dynamics and are socially embedded having many interlocked dimensions. These concepts imply to the much broader, diverse and multidimensional ideas (Castelli, 2018).

The link between environmental change and migration are extremely complex. Migration is often the result of a variety of layered causes - economic, social and political, which are accentuated by changing environmental conditions (ADB, 2000). The patterns of movement of environmental migrants also vary. These may be internal 
within a country or international; voluntary or forced; temporary or permanent (Hunter et al., 2015). Environmental factors have been placed a greater emphasis in describing migration as a response to stress between household needs and local environmental characteristics (Wolpert, 1966).

On a large scale the researchers have identified time and again, five main factors which influence people's decision to stay or go.

1. Economics - This includes employment oppurtunities, income and price of living.

2.Social- This includes the search for educational opportunities or obligations to kin, such as marriage or inheritance practices.

3.Political

4.Demographic

5.Environmental

\section{Objectives:-}

The primary objective of this study is to obtain an insight into the main cause of migration and encroachment of the forests. The specific objectives are:

To obtain an insight into the encroachment process through exploring the direct cause of encroachment done by individuals and group of individuals and its effect.

\section{Methodology:-}

Both primary and secondary data have been used for the present study. The relevant secondary data are collected from various official reports, records, documents and publications. Further field study was conducted in the months of January to June 2019. Semi structured questionnaire were used to interview the residents. This paper draws on a mixed approach comprising panel data from household questionnaire surveys, in-depth interviews, and participant observation. Household livelihood surveys were conducted in February 2019. Based on random samples of 25\% of the respective population, these surveys were conducted in Northern range of the Amchang WLS. The criteria for selection of respondents for the in-depth interview were

1. Having lived in the area for more than 20 years.

2. Earning their livelihood primarily from the forest.

3. Have newly settled in past 5 years.

Participation was based on informed and voluntary consent. Participants' observation was employed to understand perspectives of the respondents to encroachment and forest degradation.

\section{Study area:}

Amchang Wildlife Sanctuary is situated on the Southern bank of the mighty Brahmaputra and lies in the district of Kamprup (M). Geographically Amchang Wildlife Sanctuary lies within 91 $55^{\circ}$ ' E Longitude and 26 $10^{\circ}$ ' N latitude. The sanctuary falls under East Kamrup Forest Division. The total area is $78.64 \mathrm{sq} \mathrm{km}$. of this $7.7 \mathrm{sq} \mathrm{km}$ area is under encroachment including settlements that had been there prior to its upgradation to a sanctuary in 2004 . The sanctuary comprising of Amchamg, South Amchang and Khanapara Reserve Forest is spread over 7,864 hectars. The study was conducted in the Northern range of the Amchang WLS. 


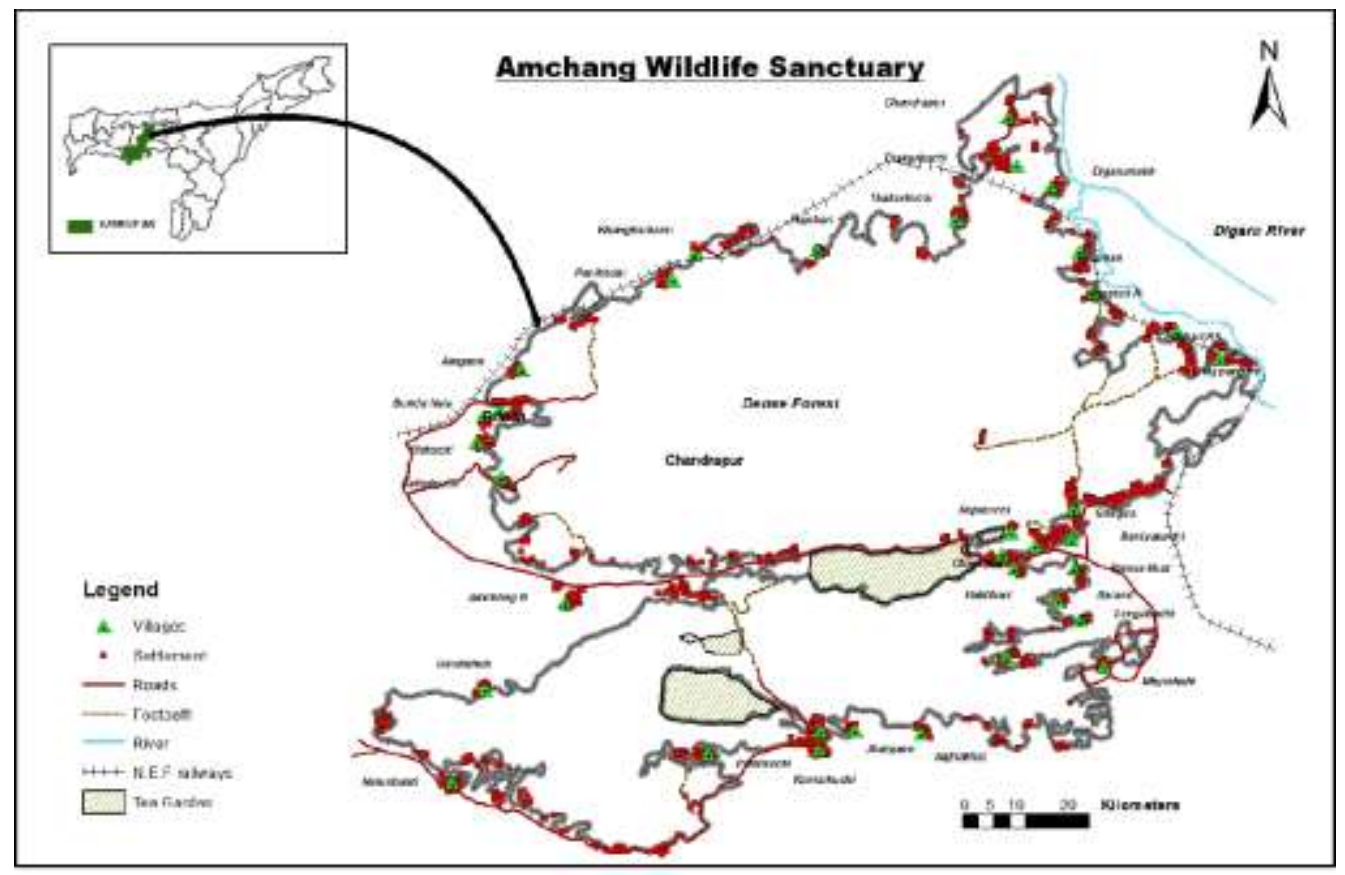

Map Source: Internet

\section{Statement of the problem:}

Amchang Wildlife Sanctuary as adjacent to Guwahati, the gateway to Northeast India is under serious threat of encroachment. The forest is threatened with excisions that convert forest land into other uses, encroachment and degradation of the forest vegetation. The degradation of the forest alters the roles of the forest including its biological richness which has not been fully documented yet. A reduction in forest roles aggravates the livelihoods of those who depend on it (FAO UN, 2011).

\section{Significance of the study:}

The growing human population against a static land resource is a threat to all forests. The Amchang Wildlife Sanctuary is faced with the threat of degradation due to human encroachment. This study sought to find out how migrants who are displaced due to various reasons are degrading the forest in terms of forest cover and ecology.

\section{Scopes and limitation of the study:}

The paper explores the risk situation and vulnerability due to environmental causes (degradation), which affects the human beings and the environment vis-a vis.

The study is a pilot survey conducted with reference to anthropogenic factors mainly focused on encroachment.

\section{Discussion:-}

"Environmental migrants" represents the terminology more often used today to describe households that have experienced an environmental "push"( White, 2015). Clearly there is tremendous variation in the extent of the push, and the ways in which environmental factors interact with other socio-economic, political and cultural forces. A useful means of considering environmental migration is on a continuum of forced to voluntary, and as related to chronic or extreme events (Hugo, 1996 and Lein, 2000).

The human settlement has shown a tremendous increase in the past two decades as has been documented in census 2011. The moderately dense forest land use has registered maximum losses during the past two decades losing an area of 1274.08 hectares. Non-forest areas like water bodies lost an area of 80.48 hectares. Non-forest areas like settlement areas have increased up to 1141.15 hectares (49.96\%) during last two decades (Changkakati, 2017). The open forest areas occupied by settlers have now started agricultural activities. Some of the water bodies disappeared in the year 2011. Due to fast growing population near the forest area as well as in the fringe villages naturally available forest resources in a sustainable manner are becoming inadequate for their basic livelihood. Many dwellers 
are engaged in farming and cattle rearing in the forest area causing irreparable damage to the forest. The erstwhile protectors of the forest are slowly turning into the bane of the forests and its wildlife.

\section{Socio-economic condition of the encroachers: Demographic characteristics:}

The areas are mostly occupied by tribal ( Bodos, Mising and Karbi in ethnicity from upper Assam) and Assamese Hindus ( from Dhubri and Goalpara). Some of the dwellers first arrived in the late 1970s and early 1990s when these hills were unoccupied. Some early settlers have continued to live on their occupied land. There is a tendency among some settlers to sell the occupied lands and encroaching further into the forest.

100 households were interviewed using semi structured questioners. It was found that $47 \%$ inhabitants settled two decades ago. Three fifth of them had come to the city in the last 15 years and $1 / 7^{\text {th }}$ of them were born in Guwahati City. It was found that many settlers have lost their land to erosion and annual floods. Many have certificate of land lost due to river erosion and Government aid to construct house. But they don't utilize the government schemes and remain occupying the land illegally.

\section{Occupation and livelihood:}

Overall wage labors are the highest rank followed by service and petty jobs. The household were low income, about $72 \%$ of them with a monthly income of less than INR 10,000. Many earn their livelihood by cutting trees from the adjacent forest. Businessmen are relatively rich and sometimes they do not live in the encroached area, rather lease out the land to factories and workshops.

\section{Cause of settlement/ encroachment:}

The relative lack of development and income opportunities outside of agriculture in the neighbouring rural areas serve as push factors to the largest city in the northeast India. With land rents and housing being high towards city, such migrants have no choice but to set up informal housing near the outer limits of the city. Tribal sold lands held by them to these migrants who have lost their land due to various reasons and moved up in the hills. Since there is no regulatory mechanism in place, ecological aspects were not considered when these land transactions took place.

The factors that propel people to leave their place of origin referred to as "push" factors include both natural disasters and gradual environmental degradation resulting from human activity. The factors that heave the people (referred to as "pull" factors) to be concentrated in hopes and expectation of better opportunities for lives and livelihoods rather the consequences of frustration and agony are observed in most cases in the city slums and other destination

\section{Encroachment process:}

The encroachment process could be divided into two types - direct encroachment and indirect or pseudo encroachment. In case of direct encroachment local or migrant encroachers live in the invaded forestland. But in pseudo encroachment local encroachers do not live in the encroached land rather lease or rented out the land to other may be local or migrant encroachers. In case of direct encroachment, poor individuals after coming to the forest frontier at first construct very small hut or houses (made of wood or earth) in the forest adjacent vacant places. Then they start to develop relationship with the local people and elites though sometimes after establishing relationship they come to new places. After initial settlement they start to clear forestland by cutting trees and convert into agricultural land. At this stage the individuals are simple illicit feller. In several instances the occupants set fire and portray as forest fire. Forest personnel very seldom visit the area and in some cases are even bribed by the settlers. The encroachers avail this opportunity to build houses on the vacant land. They plant non-forest trees (often prior to clearing of forests) to prove that they have been living in that particular place for long time. Then they encourage other people to come. Electricity connection is also availed by illegal means. As a group they construct graveyard, mosques, schools, etc. to maintain their holding rights over the land. Most often local government affiliates support them to expand their political base.

\section{Effect of encroachment:}

In this context it was found that rampant encroachment and illegal tree-felling have turned into a heavy threat for the northern part of Amchang WLS. What is more disturbing is that the existing settlements are encouraging more encroachment, with the forest authorities themselves admitting that the steps taken to contain encroachment are inadequate to meet the situation. There are more that 400 households settled in the area. 
But due to several factors including forest fire, resort development, illegal settlement etc is responsible for significant decrease in vegetation and wildlife. The rapid encroachment of the forest land in Amchang WLS which is going on unchallenged. If conservation is to thrive in the sanctuary and its buffer areas, ways and means of controlling the problem of encroachment must be rapidly sought before further habitat loss and degradation arise.

The indigenous communities maintained their lifestyle until 2004 when government Amchang Reserve Forest was upgraded to Wildlife Sanctuary. Their growing population and changing lifestyles including shifting cultivation and setting fires to the forest to improve cattle grazing pasture has become a threat the forest. As a result a major eviction effort by the government to remove these communities from the forest has been carried out time and again.

1. Fear of eviction

2. Lack of improvement of housing, lack of services like water supply.

3. Human health concers.

4. Inability to obtain various certificates leading to children denied of government scholarships

5. No access to credit.

\section{Conclusion:-}

With our understanding about the causes of migration and the consequences, the migration-environment interlinkage have become all the more clear. Much progress has been made over the past several years although certainly much more research is needed. The political, economic, and cultural contexts of population-environment association have provided better critical understanding of the roles, of globalization, inequality, population increase and vulnerability in taking decision of migration. Clearly migration-environment questions are inherently interdisciplinary. Although much work in this area has engaged scholars across disciplines, we must continue to expand these efforts. Natural science expertise is essential in accurately engaging the environmental data and the demographic community must continue to seek those interested in such collaborative work. In today's era of global climate change, and particularly in regions where natural capital is central to livelihoods, it's imperative that we measure and integrate consideration of environment's interaction with other factors in shaping migration, otherwise, our work on the migration puzzle may simply be missing a critical piece (Hunter, 2006). Encroachment is occurring in all the forest divisions at different rates. Population pressure and poverty are the main underlying causes of peoples' movement into the forest. Underlying causes of encroachment is a complex phenomenon. People encroach the forestland either to avail new economic opportunities or to avoid risks or to both. The direct causes of encroachment are embedded in the social, economic, environmental, biological, cultural, historical and political context of the country. Policymakers, thus, need to implement a wide range of developmental policies in combination with environmental ones in order to improve society's ability to effectively cope with environmental change and minimize its effect on migration.

\section{Reference:-}

1. ADB, (2000): Key indicators of developing Asian and Pacific Countries. Asian Development Bank, Oxford University Press.

2. Ahmed, N., Khan. T.I.,( 2018): Climate Change and Environmental Degradation. EJSSS, Vol. 3, Issue 1.

3. Castelli. F., (2019): Drivers of Migration: Why do people move? Journal ofTravel Medicine, Vol. 25, Issue 1.

4. Changkakati, T. (2017): "Forest cover change in Amchang Wildlife Sanctuary." Assam. Journal of Engineering Technology, Vol. 6, Issue 2, July, 2017

5. FAO, United Nations, (2011): Assessing Forest Degradation: Towards the development of Globally applicable guidelines.

6. Hunter, L. M., \& Nawrotzki, R. J. (2016). Migration and the environment. Ch 21, p.465-484. In Handbook of Migration and Population Distribution. M. J. White (Ed.). Dordrecht, Netherlands: Springer. DOI: 10.1007/97894-017-7282-2_21

7. Hugo, G. (1996): "Environmental concerns and international migration." International Migration Review 30(1):105-131.

8. Lein, H. (2000): "Hazards and 'forced' migration in Bangladesh." Norwegian Journal of Geography 54:122-127.

9. White. M.J., (2015) International Handbook of Migration and Population Distribution, Google Book.

10. Wolpert, J. (1966): "Migration as an adjustment to environmental stress." Journal of Social Issues 22(4):92-102. 